International Journal of Small Business and Entrepreneurship Research

Vol.8, No.2, pp.32-42, April 2020

Published by ECRTD-UK

Print ISSN: 2053-5821(Print), Online ISSN: 2053-583X (Online)

\title{
WORKING CAPITAL MANAGEMENT -PERFORMANCE RELATIONSHIP: A STUDY OF SMALL AND MEDIUM ENTERPRISES IN AKURE, NIGERIA
}

\author{
Simon-Oke, O.Olayemi \\ Department of Economics, \\ Federal University of Technology, P.M.B 704, Akure, Nigeria \\ E-mail: oosimon-oke@futa.edu.ng; Mobile No: +2348037734653
}

\begin{abstract}
Despite the available potentials for sustainable growth and development of Small and Medium Enterprises (SMEs) especially in developing economies, poor management of working capital has continued to deny most SMEs the optimum performance needed to annex the inherent potentials in the business. The study therefore seeks to investigate the relationship between management of working capital and Performance of small and medium enterprises; assess various sources of financing working capital; evaluate working capital management and identify problems associated with the management of working capital of SMEs in Akure, Nigeria. The study adopted descriptive survey with primary source of data collection through a wellstructured questionnaire, to elicit information from randomly selected respondents. Both the descriptive and inferential statistics were used for the analysis. The study discovered a significant and positive relationship between working capital and performance of SMEs; identified bank loan, loan from family members and friends, and personal savings as major sources of financing working capital. The study also revealed cash as mostly used of all other working capital components while ineffective management of cash appeared to be most worrisome of all the problems associated with working capital management in the study area. The study concluded that effective working capital management ensures that SMEs have enough funds for day to day running of the business, which suggests consideration for other sources of financing working capital such as cooperative societies among others, for optimum performance needed by SMEs to annex the potentials for sustainable growth and development.
\end{abstract}

Keywords: working capital, management, performance, relationship, SMEs, Akure-Nigeria JEL Classification: L25, L26, L53, M21

\section{INTRODUCTION}

The existence of large corporations in today's business environment are off-shoot of Small and Medium Enterprises that have contributed to the expansion of national outputs through value addition to the manufacturing sector, and constitute the major breakthrough in several emerging sectors, which also form most of the businesses in Nigeria. Generally, Small and Medium-Scale Enterprises (SMEs) also known as small and medium enterprises or small and medium-sized 
International Journal of Small Business and Entrepreneurship Research

Vol.8, No.2, pp.32-42, April 2020

Published by ECRTD-UK

Print ISSN: 2053-5821(Print), Online ISSN: 2053-583X (Online)

businesses (SMBs) (Wikipedia, 2016), are privately owned organizations set-up for the purposes of producing goods or services for profit maximization (Ohachosim, 2014).The abbreviation "SME" is being used by the European Union and international organizations such as World Bank, United Nations, OECD and the World Trade Organization (WTO) among others. As good as this definition appear to be, it only tells us the type of ownership (private) as well as the general reason why business is usually conceived. It does not inform us about the size of the business as well as the capital need of the business that fall into the category of business concern. This is because there is no general agreement on the standard to measure these characters of business. In facts, Ohachosim (2014) observed that there is no universal definition for SMEs since the definition depends on who is defining it and where it is being defined. This is in addition to the disparities of firms in their level of capitalization, employment and revenue. Hence, definitions which employ measures of size (net worth, profitability, turnover, number of employees, etc.) when applied to one sector could lead to all firms being categorized as small, while the same size definition when applied to a different sector could lead to different results.

Another reason for different definitions of SMEs is time, place, prevailing economic condition and level of technological know-how in different countries. For instance, what is regarded as a large firm today may be actually an SME in the very near future and what is considered an SME in developed countries like United States of America may be a large firm in developing countries like Nigeria (Ohachosim, 2014).

The European Commission also classified SME into three for the purpose of defining the term. These include: medium sized with the number of employee less than 250 and turnover of less than equal to 50 million euro, Small sized with less than 50 employees and turnover of less than equal to 10 million euro and lastly Micro sized of less than 10 employees and less than equal to 2 million euro. EU member states have their individual definitions as well. For example, Germany had a bound of 255 employees, whilst in Belgium it could go for a value of 100 (Wikipedia, 2016). Similarly in Canada (North America), a small business as one with fewer than 100 paid employees and a medium-sized business as one with at least 100 and fewer than 500 employees. Under the Venture capital trust fund Act, 2004 (Act 680) of Ghana, a small and medium scale enterprise (SME) as an industry, project undertaking or economic activity whose total asset base (excluding land and building) does not exceed the cedi equivalent of \$1 million US dollars in value (Sydney, 2012).

In the Nigeria context, The Central Bank of Nigeria defines small and medium enterprises in Nigeria according to asset base and number of staff employed. The criteria are an asset base equal or less than N5 million, and a staff strength equal or less than 100 employees. Small and Medium Industries Equity Investment Scheme (SMIEIS) defined SMEs as those "enterprises with a total 
International Journal of Small Business and Entrepreneurship Research

Vol.8, No.2, pp.32-42, April 2020

Published by ECRTD-UK

Print ISSN: 2053-5821(Print), Online ISSN: 2053-583X (Online)

capital employed not less than N1.5 million, but not exceeding N200 million, including working capital, but excluding cost of land and / or with a staff strength of not less than 10 and not more than 300 (Obamuyi, 2007). It seems the Nigerian National Policy on MSME's has addressed grey areas in the definition as to what characterize micro, small and medium enterprises. The National Bureau of Statistics (2012) also makes classification with respect to definitions adopted by the national policy, based on dual criteria of employment and assets which exclude land and buildings.

Apart from various definitions of SMEs expressed by different sources and the established reasons for such definitions, the various concepts of working capital are also stated by different scholars, for instance working capital refers to the funds needed to pay for the daily operations of the business, which are the short-term drivers of an organization (Kehinde, 2011). Also, according to Adeniji (2008) working capital is the difference between an organization's current assets and its current liabilities. Of more importance to this definition is its function which is primarily to support the day-to-day financial operations of an organization, including the purchase of stock, the payment of salaries, wages and other business expenses and the financing of credit sales among others (Adeniji, 2008).

Meanwhile, the management of working capital is more essential for the success of SMEs, which involves planning and controlling current assets and current liabilities in a manner that eliminates the risk of inability to meet due short term obligations on the one hand and avoid excessive investment in these assets on the other hand (Eljelly, 2004).Working capital management as a managerial accounting strategy focuses on maintaining efficient components' level of working capital (that is, current assets and current liabilities) in respect to each other. Implementing an effective working capital management system is an excellent way for many SMEs to improve their earnings. Working capital management may involve implementing short-term decisions that may or may not carry over from one financial period to the next (Donkor, 2015). Not getting the management of components of working capital right spells doom for SMEs "not doing well".

The ability of SMEs to manage their Working capital would practically ensure sufficient cash flows to meet its short-term debt obligations and operating expenses. Working capital management has thus, become a basic and broad aspect of assessing the performance of a corporate entity. It is, therefore, essential to maintain an adequate degree of liquidity for the operational activities of SMEs. The successful management of Working Capital enables a firm to react quickly and appropriately to unanticipated changes in market variables, such as interest rates and raw material prices in order to gain competitive advantages over its competitors. (Ansah, 2011; Mwanahamisi, 2013). 
International Journal of Small Business and Entrepreneurship Research

Vol.8, No.2, pp.32-42, April 2020

Published by ECRTD-UK

Print ISSN: 2053-5821(Print), Online ISSN: 2053-583X (Online)

Operations of SMEs in Nigeria, like their counterparts in the developed economies holds a lot of potentials for sustainable development but how to effectively and efficiently manage working capital to the benefit of their organizations, i.e. maintaining optimal balance between each element forming working capital constitutes major challenges. This is because working capital comprises a number of different items and its management is difficult since these are often linked. Hence, altering one item may impact adversely upon other areas of the business (Ansah, 2011). Poorly managed working capital often leads to tying up funds in the assets in form of stocks and reduces the liquidity and profitability of an organization. It will also result in cash flow problems highlighted by an organization exceeding its agreed overdraft limit, failing to pay suppliers on time, and being unable to claim discounts for prompt payment. In the long run, a business with insufficient working capital will find it difficult to meet its current obligations and be forced out of business even if it remains profitable on paper (Ansah, 2011). Poor management of working capital constitutes a major challenge facing most SMEs, which eventually lead to their extinction within a short period of their existence. Therefore, this study seeks to examine the relationship between management of working capital and performance of small and medium enterprises in Akure, Nigeria; with specific intents to assess various sources of financing working capital by SMEs; evaluate the components of working capital management in SMEs and identify problems associated with the management of working capital of SMEs in the study area.

\section{RESEARCH METHOD}

The study adopted descriptive survey with the use of primary source of data collection through a structured questionnaire, to elicit information from the respondents. The study was concentrated

in Akure Metropolis of Ondo state in Nigeria where most of the business activities in the state particularly the SMEs are located. Moreso, the chief executives (CEOs) of the entire registered SMEs located across the length and breadth of the state (Numbering about 975), based on 2018 estimates of the Small and Medium Enterprises Development Agency in Ondo State were considered as population of the study. The simple random sampling procedure with sample size of 284 SMEs using the Taro Yamane scientific formulae (Yamane, 1967) was also considered such that;

$$
\mathrm{n}=\frac{\mathrm{N}}{1+\mathrm{N}(\mathrm{e})^{2}}
$$

Where $\mathrm{n}$ is sample size, $\mathrm{N}$ is population size, and e is margin of error (0.05).

$$
\begin{aligned}
& \mathrm{n}=\underline{975} \\
& \mathrm{n}=\underline{1+975}(0.050)^{2} \\
& \mathrm{n} \quad=\underline{975}
\end{aligned}
$$


International Journal of Small Business and Entrepreneurship Research

Vol.8, No.2, pp.32-42, April 2020

Published by ECRTD-UK

Print ISSN: 2053-5821(Print), Online ISSN: 2053-583X (Online)

$$
\begin{array}{ll} 
& 1+2.4375 \\
\mathrm{n}= & \underline{975} \\
& 3.4375 \\
\mathrm{n} \quad= & 283.64 \\
\mathrm{n} \quad \text { is approximately equal to } 284 .
\end{array}
$$

Meanwhile, a total of 284 copies of questionnaire were administered on the respondents, out of which 262 copies were returned and analysed.

The study adopted both descriptive and inferential statistics as analytical tools. The descriptive statistics used includes frequency counts, simple percentages as well as mean value while inferential statistics of Pearson Product-Moment Correlation Coefficient (PPMC) was also employed using the following formulae:

$r=r_{x y}=\frac{n \sum x_{i} y_{i}-\sum x_{i} \sum y_{i}}{\sqrt{n \sum x_{i}^{2}-\left(\sum x_{i}\right)^{2}} \sqrt{n \sum y_{i}^{2}-\left(\sum y_{i}\right)^{2}}}$.

Pearson correlation coefficient, $r$, is subject to the constraint: $-\mathbf{1} \leq \boldsymbol{r} \leq+\mathbf{1}^{-1} \leq r_{s} \leq 1$

Where $\mathbf{x}$ and $\mathbf{y}$ represent variables in a pair whose association was tested; $\mathbf{n}=$ Number of pairs of values of each variable. Also in addition, test of hypothesis was conducted to ascertain the significant level of each of the variables using Statistical Package for Social Science (SPSS) version 20; with the following decision rule:

(i) Accept the Null hypothesis $\left(\mathrm{H}_{0}\right)$ if significance probability ${ }^{p p}$ is equal or greater than the level of significance of 0.01 , correlation is not significant.

(ii) Reject the Null hypothesis $\left(\mathrm{H}_{0}\right)$ if significance probability ${ }^{p p}$ is lesser than the level of significance of 0.01 , correlation is significant.

\section{RESULTS AND DISCUSSION}

\section{Assessment of Various Sources of Financing Working Capital adopted in SMEs}

SMEs in the study area explored different sources of working capital. Respondents were asked to identify different sources of working capital available and ranked them in order of importance. Their responses were used to calculate the mean value for each of the sources as presented in Table 1 and arranged in descending order (highest to the lowest).Table1 indicated that Bank loan (Overdraft) was ranked the highest among others with a mean value of 4.77 followed by loan from family members and friends(4.35), personal savings/ Retained earnings (3.85) and NGOs (3.85) ranked second, third and fourth respectively; while accruals (2.44) and accounts payable (2.42) ranked in the fifth and sixth positions. The implication is that the SMEs in Akure mostly adopted conservative financing approach which is the use of long term loan to finance their 
International Journal of Small Business and Entrepreneurship Research

Vol.8, No.2, pp.32-42, April 2020

Published by ECRTD-UK

Print ISSN: 2053-5821(Print), Online ISSN: 2053-583X (Online)

working capital needs, followed by matching approach and aggressive approach respectively. This is in agreement with the study of Pass \& Hike (2007). Also, the implication of choice of internal financing of businesses with personal saving / retained earnings is that no floatation cost is incurred and no additional disclosure of financial information is required that could possibly lead to loss of competitive advantage, which also agrees with the study of Weda (2015).

Table1: Sources of Financing Working Capital in the study area

\begin{tabular}{lll}
\hline Sources & Mean & Ranking \\
Bank loan & 4.77 & 1 st \\
Loan from family members and friends & 4.35 & 2nd \\
Personal saving / retained earnings & 3.85 & 3rd \\
NGOs & 3.85 & 4 th \\
Accruals & 2.44 & 5 th \\
Account payable & 2.42 & 6th \\
\hline
\end{tabular}

Source: Computed Field survey, 2017

\section{Management of Working Capital in SMEs}

The study identified the components of working capital management assessed by the respondents namely Cash and Inventory management; Account receivable and Account payable management among others.

\section{Cash and Inventory Management}

Cash management is an integral part of working capital management. There are three major reasons for holding cash for business operation, which include precautionary, speculative and transactionary motives. The exact respondents position in Table 2 shows the transactionary motive as the most popular of the three reasons why SMEs hold cash with 45.1 percent (128) respondents while precautionary reason for cash holding was next 29.6 percent (84), and lastly speculative reason 25.4 percent (72) appeared the least of all the motives for holding cash by SMEs in the study area. The implication of this is that many of the SMEs in the study area preferred to hold cash to facilitate day to day business transaction rather than for unforeseen fluctuation in cash flow, and to take advantage of any business bargain that might arise.

Inventory on the other hand comprises materials needed for production; work in progress and finished goods to be sold. The study also sought to investigate the inventory management approach used by the respondents. The respondents' view in Table 2 also show that 46.5 percent (132) of the respondents used Just in time approach, 26.4 percent (72) considered sales forecast, and 24.4 percent (72) adopted Economic Order Quantity (EOQ) approach, while 2.8 percent (8) used ABC method. This result placed just-in-time inventory management approach above other approaches 
International Journal of Small Business and Entrepreneurship Research

Vol.8, No.2, pp.32-42, April 2020

Published by ECRTD-UK

Print ISSN: 2053-5821(Print), Online ISSN: 2053-583X (Online)

in the management of working capital by SMEs in the study area. The implication of this according to Mintzberge (1979) is that business firms would be at advantage position to annex internal working capital variables to the changing environmental aspects of the firms operating at highly unpredictable business environment.

Table 2: Cash and Inventory Management by SMEs in the study area

\begin{tabular}{llll}
\hline Motive for holding cash & Frequency & Percentage & Ranking \\
\hline Precautionary motive & 84 & 29.6 & $2 \mathrm{nd}$ \\
Speculative motive & 72 & 25.4 & $3 \mathrm{rd}$ \\
Transactionary motive & 128 & 45.1 & $1 \mathrm{st}$ \\
Inventory Management Approach & & & \\
Just- in- Time & 132 & 46.5 & $1 \mathrm{st}$ \\
ABC method & 8 & 2.8 & 4 th \\
Sales forecasting & 72 & 26.4 & $2 \mathrm{nd}$ \\
Economic Order Quantity (EOQ) & 72 & 24.4 & $3 \mathrm{rd}$ \\
\end{tabular}

Source: Computed Field survey, 2017

\section{Management of Account Receivable and Account Payable in SMEs}

Table 3 shows various opinions of respondents on the management of account receivable and account payable by SMEs in the study area. Some respondents, that is 33.8 percent (96) prefer to make use of accounts receivable (from debtors) for financial motives, 31 percent (88) used accounts receivable due to price motive, 23.4 percent (68) used accounts receivable because of transactionary motive, while operative motive and tax based motive were the reasons stated by 7.0 percent (20) and 4.2 percent (12) of the respondents respectively for using accounts receivable. Also, the account payables are usually motivated by some factors such as discounts, reduced price and after sales services among others. The account payable records shown in Table 3 established that discounts motivates higher than other motivating instruments offered by the suppliers to SMEs in the study area, with 49.3 percent respondents (140) favoured discounts, followed by reduced Price 33.8 percent (96) and lastly availability of after sales services with 16.9 percent (48). The implication of the result in Table 3 is that SMEs allow account receivables for financial motive i.e to finance some if not all of their payables but with a caution to reduce credit period in order to avoid unfavorable effect of keeping the business from benefiting from capital inflow that might arise from credit sales. Also, account payables are motivated mostly because of discount offered by the suppliers. This is an attempt to get SMEs to pay before maturity date but effort should be made to evaluate whether discount rate offered is higher than interest rate the business would have to pay for a loan over the same period as the discount period (Maness \& Zietlow, 2005). 
International Journal of Small Business and Entrepreneurship Research

Vol.8, No.2, pp.32-42, April 2020

Published by ECRTD-UK

Print ISSN: 2053-5821(Print), Online ISSN: 2053-583X (Online)

Table 3: Account Receivable and Account Payable by SMEs in the study area

\begin{tabular}{llll}
\hline Causes of Account Receivable & Frequency & Percentage & Ranking \\
\hline Price motive & 88 & 31.0 & $2 \mathrm{nd}$ \\
Financial motive & 96 & 33.8 & $1 \mathrm{st}$ \\
Operating motive & 20 & 7.0 & 4 th \\
Transactionary motive & 68 & 23.9 & $3^{\text {rd }}$ \\
Tax based motive & 12 & 4.2 & 5 th \\
Factors motivating Account Payable & & & \\
Discounts & 140 & 49.3 & 1 st \\
Reduced prices & 96 & 33.8 & $2 \mathrm{nd}$ \\
After sales services & 48 & 16.9 & $3 \mathrm{rd}$
\end{tabular}

Source: Computed Field survey, 2017

\section{Problems of Working Capital Management in SMEs}

The study revealed some of the challenges associated with the management of working capital of SMEs in the study area in order of severity as described by the respondents in Table 4 . The various confronting problems of SMEs identified by the respondents in Table 4 also shows the descending order of severity as follows: ineffective cash management has the highest severity index of 0.92 , unskilled personnel in the management of working capital has severity index of 0.89 , lack of computer literacy to manage working capital has severity index of 0.69 , inadequate use of modern technology has 0.62 severity index, inadequate access to finance working capital has 0.60 , while Poor receivable collection period has the least severity index of 0.55 .

It can be inferred from the list of problems identified in Table 4 that a sizable number of business firms do not prepare cash budget in their day-to-day operations; while unskilled personnel in financial management coupled with lack of information technology proficiency that can introduce modern technology in SMEs operations contribute to the shortcomings in the growth of the SMEs in the study area. In addition, inadequate access to loan facilities due to processing bottleneck to finance operation of SMEs has adverse effect on their activities. Also, the poor credit collection policy that in most cases resulted into huge amount of bad debt can also lead to extinction of some of the SMEs within a short period of their existence (Ansah, 2011). 
International Journal of Small Business and Entrepreneurship Research

Vol.8, No.2, pp.32-42, April 2020

Published by ECRTD-UK

Print ISSN: 2053-5821(Print), Online ISSN: 2053-583X (Online)

Table 4: Problems Associated with Working Capital Management in SMEs

Problems Mean SI

Ineffective management of cash

$4.59 \quad 0.92$

Unskilled personnel in the management working capital

$\begin{array}{ll}4.47 & 0.89\end{array}$

Lack of computer literacy to manage working capital

$3.47 \quad 0.69$

Inadequate use of modern technology e.g ERP

$3.10 \quad 0.62$

Inadequate access to finance working capital

$2.99 \quad 0.60$

Poor receivable collection period

$2.76 \quad 0.55$

Source: Computed Field survey, 2017

\section{Working Capital Management and Performance of SMEs}

Hypothesis was tested to show the relationship between working capital management and the performance of small and medium enterprises in Akure, Ondo State, Nigeria. The study working hypothesis is stated thus:

$\mathrm{H}_{0}$ : There is no significant relationship between working capital management and performance of small and medium enterprises.

$\mathrm{H}_{1}$ : There is significant relationship between working capital management and performance of small and medium enterprises

Table 5 shows the result of Pearson Correlation which was used to ascertain the nature of relationship between working capital management and performance of small and medium enterprises in the study area. The result shows positive but weak relationship (with correlation coefficients $=0.397$ ) between working capital management and performance of small and medium enterprises in Akure. The significant probability for this relationship is .000 at 0.01 significant level (2-tailed), and since the significant probability for the stated hypothesis is less than 0.01 (2tailed), the null hypothesis is rejected, whereas the alternate hypothesis is accepted. Therefore, there is significant relationship between working capital management and the performance of small and medium enterprises in the study area. 
International Journal of Small Business and Entrepreneurship Research

Vol.8, No.2, pp.32-42, April 2020

Published by ECRTD-UK

Print ISSN: 2053-5821(Print), Online ISSN: 2053-583X (Online)

Table 5: Relationship between Working Capital Management and Performance of SMEs in the study area

\begin{tabular}{|l|l|l|l|}
\hline \multicolumn{2}{|l|}{} & Working Capital Management & $\begin{array}{l}\text { Performance } \\
\text { of SMEs }\end{array}$ \\
\hline \multirow{2}{*}{$\begin{array}{l}\text { Working } \\
\text { Capital } \\
\text { Management }\end{array}$} & Pearson Correlation, $\boldsymbol{r}$ & 1 & $.397^{* *}$ \\
\cline { 2 - 4 } & Sig. (2-tailed) & & .000 \\
\hline \multirow{2}{*}{$\begin{array}{l}\text { Performance } \\
\text { of SMEs }\end{array}$} & Pearson Correlation, $\boldsymbol{r}$ & 284 & 284 \\
\cline { 2 - 4 } & Sig. (2-tailed) & $.397 * *$ & 1 \\
\cline { 2 - 4 } & $\mathrm{N}$ & .000 & 284 \\
\hline
\end{tabular}

** Correlation is significant at the 0.01 level (2-tailed) -if the significant probability is equal or greater than the level of significance, correlation is significant, $\boldsymbol{r}$-Pearson correlation coefficient, $\mathrm{N}$ - Number of Respondents

Computed Field Survey, 2017

\section{CONCLUSION AND RECOMMENDATION}

The study seeks to examine the relationship between management of working capital and the Performance of small and medium enterprises in Akure, Nigeria, with specific intents to assess various sources of financing working capital by SMEs; evaluate the components of working capital in SMEs and identify problems associated with the management of working capital of SMEs among others in Akure metropolis using both descriptive and inferential statistics as tools for analysis. Apart from the challenges facing SMEs in the study area, it could also be established that effective management of cash, account receivables, account payables and inventory are very important to the performance of SMEs, which suggests implementation of effective cash management policies such as budgeting and preparation of cash flow statement; credit analysis and collection policy for effective and efficient account receivable and account payable management system. The efficiency of working capital management also ensures that SMEs have enough funds for day to day running of the business, which also suggests consideration for other sources of financing working capital such as Cooperative Societies among others for optimum performance needed by SMEs to annex the potentials for sustainable growth and development.

\section{References}

Adeniji, A.A., (2008).Management Accounting. $4^{\text {th }}$ edition, El Toda Venture Limited, Lagos, Nigeria

Ansah, O. S. (2011).Effective Management of Working Capital is the Life: An Assessment of Working Capital Management Practices. Unpublished Thesis Submitted to The Institute of Distance Learning, Kwame Nkrumah University of Science and Technology in Partial Fulfillment of the Requirements for the Award of Commonwealth Executive Master's Degree in Business Administration. 
International Journal of Small Business and Entrepreneurship Research

Vol.8, No.2, pp.32-42, April 2020

Published by ECRTD-UK

Print ISSN: 2053-5821(Print), Online ISSN: 2053-583X (Online)

Donkor, J. (2015).Working Capital Management of SMEs: Ghana's version of the story. British Journal of Economics, Management and Trade, 10(3), 1-12.

Eljelly, A.M.(2014).Liquidity-Profitability Trade-off: An Empirical Investigation in an Emerging Markets. International Journal of Commerce and Management, 14(2), 48-61.

Kehinde, J.S. (2011).Effective Working Capital Management in Small and Medium Scale Enterprises (SMEs). International Journal of Business and Management, 271- 279.

Maness, T. S. \& Zietlow, J.T. (2005).Short-Term Financial Management, Ohio: SouthWestern/Thompson learning.

Mintzberge,H.(1979). The Structuring of Organization.Englewood,Cliffs N.J:Prentice Hall.

Mwanahamisi, A. W. (2013). Effects of Working Capital Management on the Performance of Firms in Kenya: A Case Study of Kenya Ports Authority. International Journal of Science and Research (IJSR), 4(4), 1124-1136

NBS (2012). Annual Abstract of Statistics. Abuja: National Bureau of Statistics.

Obamuyi,T.M.(2007).An Exploratory Study of Loan Delinquency among Small and Medium Enterprises (SMEs) in Ondo State,Nigeria.Journal of labour and Management in Development, Vol.8,1-11.

Ohachosim, C. I. (2009).Financial Challenges of Small and Medium-Scale Enterprises (SMES), in Anambra State, Nigeria, University of Nigeria. Enugu: An Unpublished Master of Science (M.Sc.) in Accountancy Dissertation Presented to The Department of Accountancy, Faculty of Business Administrations, University of Nigeria, Enugu Campus.

Pass C.L. \& Pike, R.H. (2007). An Overview of Working Capital and Corporate Financing. Journal of Managerial Finance, 10(3), 1-11

Sydney. (2012).The Development of Small and Medium Enterprises and their impact to the Ghanaian Economy. An Unpublished thesis submitted to the Institute of Distance Learning, Kwame Nkrumah University of Science and Technology for the Degree of Masters in Business Administration (M B A)

Weda, C. W. (2015).Influence of Working Capital Management Practices on Financial Performance of Small and Medium Manufacturing Enterprises in Nairobi, Kenya. An Unpublished thesis Submitted in Partial Fulfillment for the Degree of Doctor of Philosophy in Business Administration and Finance at the Jomo Kenyatta University of Agriculture And Technology.

Wikipedia (2016).http://en.wikipedia.org/wiki/small and medium enterprises. Access date, July, 2016

Yamane. (1967).Statistics: An Introduction Analysis. $2^{\text {nd }}$ edition, Harper and Row, New York. 